populations who are heterogeneous with regard to risk susceptibility. The patient with above average susceptibility may develop risk factors, though his or her behaviour may not be aberrant in statistical terms.

The first approach confirms the importance of individual prevention and care, whereas the second shows that prevention is necessary also at the level of populations.

We thank Ms G Cohier, $M$ Lagrost, C Chabert, $H$ Eydoux, C Marcoul, and $S$ Perles for collecting the survey data and Dr B Krajevitch for examining the children.

1 Rolland-Cachera MF, Bellisle F. No correlation between adiposity and food intake: why are working class children fatter? Am $\mathcal{F}$ Clin Nutr 1986;44:779-87.

2 Keen H, Thomas BJ, Jarrett RJ. Obesity and cardiovascular risk. Int $\mathcal{f}$ Obes 1982;6:83-9.

3 Poskitt EME, Cole TJ. Nature, nurture, and childhood overweight. Br Med f 1978;i:603-5.

4 Fehily AM, Phillips KM, Yarnell JWG. Diet, smoking, social class and body mass index in the Caerphilly heart disease study. Am f Clin Nutr 1984;40:827-33.

5 Sub-Committee on Non-Pharmacological Therapy of the 1984 Joint National Committee on

Detection, Evaluation, and Treatment of High Blood Pressure (USA). Non-pharmacological

approaches to the control of high blood pressure. Final report. Hypertension 1986;8:444-67.

(Accepted 9 December 1987)

Section de Nutrition, Centre de Recherche du Vésinet, Institut National de la Santé et de la Recherche Médicale, 78110 Le Vésinet, BP 34, France

MARIE FRANCQISE ROLLAND-CACHERA, SCD, chargée de recherches MICHËLE DEHEEGER, BSC, dietitian

FRANCOISE PÉOUIGNOT, CESAM, medical statistician

MICHEL GUILLOUD-BATAILLE, DUT, assistant ingénieur

FRANÇOISE VINIT, BTS, assistante scientifique

Laboratoire de Neurobiologie de la Nutrition, Ecole Pratique des Hautes Etudes, Collège de France, 75231 Paris

FRANCE BELLISLE, SCD, chargée de recherches, Centre National de la Recherche Scientifique

Correspondence to: Dr Rolland-Cachera.

\section{Intrauterine growth and neonatal weight gain in babies of women with anorexia nervosa}

Babies of women with a low weight before pregnancy are smaller than average and have an increased perinatal mortality. ${ }^{1}$ This report describes the outcome of seven pregnancies in women with anorexia nervosa who conceived despite remaining low in weight.

\section{Patients and results}

Six of the 327 patients who started to attend the eating disorder clinic at Maudsley Hospital over the past three years conceived while their body mass index was low (median $16 \cdot 8 \mathrm{~kg} / \mathrm{m}^{2} ;$ range $14 \cdot 9-18 \cdot 1 \mathrm{~kg} / \mathrm{m}^{2}$ ). Only one of the seven pregnancies in these six women was induced (with clomiphene).

All six women had had anorexia nervosa for a long time (median 15 years, range 11-17) and were relatively old at the time of pregnancy (median 31 years, range 28-36). None smoked. Four women were primiparous, two had had earlier pregnancies terminated, and one had had a $3200 \mathrm{~g}$ baby before developing anorexia nervosa. Their average weight gain during pregnancy was $8 \mathrm{~kg}$ (range 5-14); this compared with the minimum recommended weight gain of $11 \mathrm{~kg}$.

Fetal growth was determined by serial ultrasonography in five patients. The rate of growth of the abdominal circumference of the five fetuses was diminished during the last trimester, and the abdominal circumference of all seven babies was below the third centile at birth. Nevertheless, accelerated growth was seen in all these babies during the first few months after birth (figure). Five of the six women had difficulty breast feeding and introduced bottle feeding in the first few weeks.

\section{Comment}

Several points of interest arise from these findings. Firstly, women with chronic anorexia nervosa may menstruate and even conceive despite maintaining their weight at suboptimal levels. This confirms previous reports. ${ }^{2}$ Secondly, the poor fetal growth during the third trimester probably reflected a degree of intrauterine malnutrition, but "catch up" growth was evident in the neonatal period. This is contrary to findings in other babies, who failed to thrive in their first year and showed poor catch up growth. ${ }^{3}$

Long term follow up will be required to ascertain whether these small for gestational age babies are at risk of impaired growth and neurodevelopmental
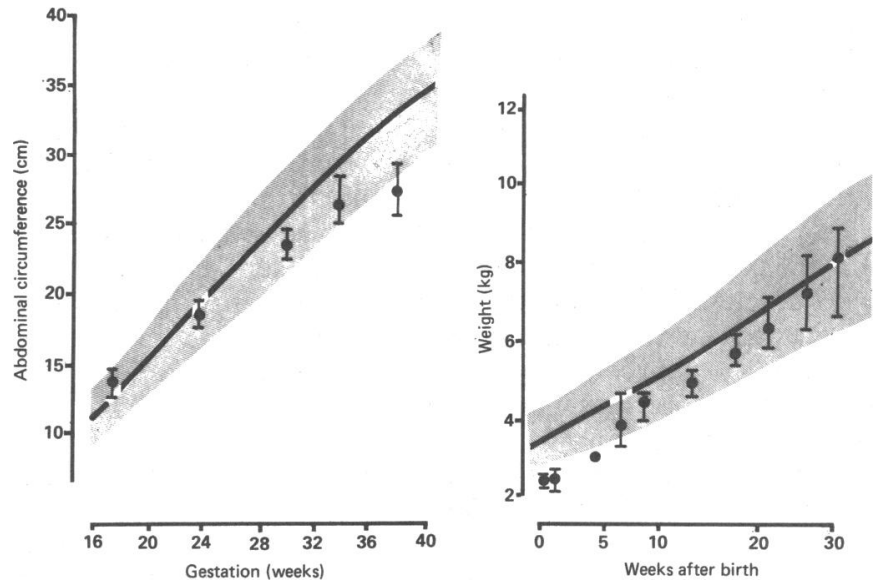

Intrauterine and postnatal growth of babies of anorectic mothers. Intrauterine growth is represented by median abdominal circumference (and range) in five fetuses as measured by ultrasonography. Postnatal growth is represented by weights from birth to six months (median and ranges refer to seven babies, except at four weeks (one baby) and after 20 weeks (three babies)). Heavy lines and shaded areas indicate mean ( $2 \mathrm{SD})$ values in normal populations.

sequelae. ${ }^{4}$ Mothers with anorexia nervosa may underfeed their children, although this is probably rare. The children of four patients attending our clinic had been investigated for poor growth, which was attributed to poor feeding. ${ }^{5}$

1 Van der Spuy ZN. Nutrition and reproduction. Clin Obstet Gynaecol 1985;12:579-604.

2 Namir S, Melman KN, Yager J. Pregnancy in restricter type anorexia nervosa. A study of six women. Intermational fournal of Eating Disorders 1986;5:837-45.

3 Illingworth R. The normal child. 8th ed. Edinburgh: Churchill Livingstone, 1983:53-75

4 Nilsen ST, Finn PH, Bergsjo P, Stamnes O. Males with low birth weight examined at 18 years of age. Acta Paediatr Scand 1984;73:168-75.

5 Smith SM, Hanson R. Failure to thrive and anorexia nervosa. Postgrad Med f 1972;48:382-4

(Accepted 23 December 1987)

Institute of Psychiatry, London SE5 8AF

J L TREASURE, PHD, MRCPSYCH, lecturer

G F M RUSSELL, FRCP, FRCPSYCH, professor of psychiatry

Correspondence to: Dr Treasure.

\section{An unusual complication of removal of a nasogastric tube}

We describe a previously unreported complication of removal of a nasogastric feeding tube.

\section{Case report}

A 21 year old man with cerebral palsy was admitted with an empyema, which was treated by decortication. Postoperatively he required enteral feeding. A narrow bore ( 9 French gauge) Silastic tube with a bolus weighted with tungsten (Viomedex) was passed through the right nostril into the stomach, and its position was confirmed radiographically. Nasogastric feeding was stopped after 15 days, and attempts were made to remove the tube. It became stuck with a few centimetres still in the nose. Gentle manipulation failed to move the tube in either direction, and on gentle traction the tube became detached from the tungsten bolus, which remained in the nostril. The bolus had become impacted behind a septal spur and become buried beneath the mucosa. It was removed under general anaesthesia. The patient recovered without further incident and was discharged soon afterwards.

\section{Comment}

Soft, small bore tubes have replaced large bore ones for enteral feeding because they are more comfortable and cause less irritation of the nasopharynx and oesophagus, reducing the risk of stenosis. Two types of narrow bore tube are commonly used: those with a weighted bolus at the distal end and those without, which are passed over a guidewire. Complications associated with passing these tubes include oesophageal perforation, 
inadvertent tracheobronchial intubation, ${ }^{2}$ pneumothorax ${ }^{3}$ and bronchopleural fistula. ${ }^{4}$ Displacement of the tube during feeding may cause aspiration pneumonia.

Weighted tubes have a lower risk of misplacement and displacement but are more difficult to pass in uncooperative patients. The complication reported here was potentially serious. We do not know of any previous reports of difficulty in removing a nasogastric tube or of the tube breaking.

The manufacturers (Vidomedex) admit that removal can be difficult and suggest that the nostril should be examined before the tube is passed. If difficulty is encountered during removal they suggest trying to advance the tube again, retrieve the weight from the pharynx, cut it off, and remove it through the mouth. The firm impaction of the weight made subsequent advance or withdrawal of the tube impossible in our patient.

It is easy to see how the weight could become lodged behind a septal spur or a turbinate bone on removal. In such cases we therefore agree with the manufacturers' advice that per oral removal should be tried. In a patient with a narrow nostril a tube without a weight passed over a guidewire may be safer.

1 James RM. An unusual complication of passing a narrow bore nasogastric tube. Anaesthesi 1978;33:716-8.

2 Stark P. Inadvertent nasogastric tube insertion into the tracheo-bronchial tree. Radiolog 1982;142:239-40.

3 Eldar S, Meguid MM. Pneumothorax following attempted nasogastric intubation for nutritional support. Fournal of Parenteral and Enteral Nutrition 1984;8:450-2.

4 Sheffner SE, Gross BM, Birnberg FA, Birk P. Iatrogenic bronchopleural fistula caused by feedin tube insertion. I Can Assoc Radiol 1985;36:52-5.

5 Metheny NA, Spiers M, Eisenberg P. Frequency of naso-enteral tube displacement and associated risk factors. Res Nurs Health 1986;9:241-7.

(Accepted 27 Fanuary 1988)

Regional Department of Thoracic Surgery, East Birmingham Hospital, Birmingham B9 5ST

$\mathrm{NC}$ HICKEY, $\mathrm{MB}, \mathrm{CHB}$, registrar in thoracic surgery

DCT WATSON, FRCS, consultant thoracic surgeon

Correspondence to: Miss D C T Watson.

\section{Skeletal muscle necrosis in severe falciparum malaria}

We report skeletal muscle necrosis in a patient with severe falciparum malaria. The patient developed myoglobinuria and acute renal failure. So far as we know this complication of falciparum malaria has not previously been described.

\section{Case report}

A previously healthy 17 year old youth was admitted complaining of fever without rigors for four days, severe muscle pains associated with the passage of dark red urine for two days, and reduced urine output for one day. He had visited an area endemic for malaria two weeks before admission. There was no history of contact with heavy metals, trauma, convulsions, strenuous exercise, injections, insect stings, or snakebite or a past history of malaria. He did not drink alcohol or abuse narcotics and had not taken any medicines. He was feverish $\left(39^{\circ} \mathrm{C}\right)$ and jaundiced with generalised muscle tenderness and minimal hepatosplenomegaly. Physical examination showed no other abnormality. Urine output was 0.4 during the first day in hospital.

\section{INVESTIGATIONS AND TREATMENT}

The blood film showed asexual forms of Plasmodium falciparum $\left(9 \times 10^{9}\right.$ infected red cells/l). There was myoglobinuria, bilirubinuria, and mild albuminuria but no haemoglobinuria. The urine deposit contained granular casts but no haemosiderin. Haemoglobin concentration was $118 \mathrm{~g} / 1$. Packed cell volume and blood cell counts were normal, with no evidence of haemolysis. Erythrocyte sedimentation rate was $110 \mathrm{~mm}$ in the first hour, plasma urea concentration $39.8 \mathrm{mmo} / \mathrm{l}$, serum creatinine concentration $795.6 \mu \mathrm{mol} / 1$, urinary sodium excretion $58 \mathrm{mmol} / \mathrm{l}$, urine urea: plasma urea ratio 1.85 , and serum potassium concentration $6.2 \mathrm{mmol} / \mathrm{l}$. Serum sodium, calcium, and phosphate values wer normal. Serum bilirubin was $102 \mu \mathrm{mol} / 1$ (conjugated bilirubin $93.3 \mu \mathrm{mol} / \mathrm{l}$ ), serum alkaline phosphatase activity $170 \mathrm{IU} /$ (normal 20-100), prothrombin time 12 seconds (ratio 1 ), plasma fibrinogen concentration $2.5 \mathrm{~g} / 1$, serum alanine transaminase activity $44 \mathrm{IU} / 1$, serum aspartate transaminase activity $130 \mathrm{IU} / \mathrm{l}$, and serum creatine kinase activity 308 IU/l (normal 10-80). Quadriceps muscle biopsy showed foci of muscle fibre necrosis with mononuclear cell infiltration (figure). Liver biopsy showed centrizonal cholestasis without necrosis or cell infiltration.
The following investigations gave negative or normal results: electrocardiograhy, chest $x$ ray, blood culture, blood and urine culture for leptospira, Wida reaction and clot culture for salmonella, Paul-Bunnell test, paired serum samples for antibodies against dengue (type 1 to 4), Japanese encephalitis, Coxsackie B (types 1 to 6), viruses, and leptospira, serum for hepatitis B surface antigen, serum proteins, antinuclear factor, and Coombs test.

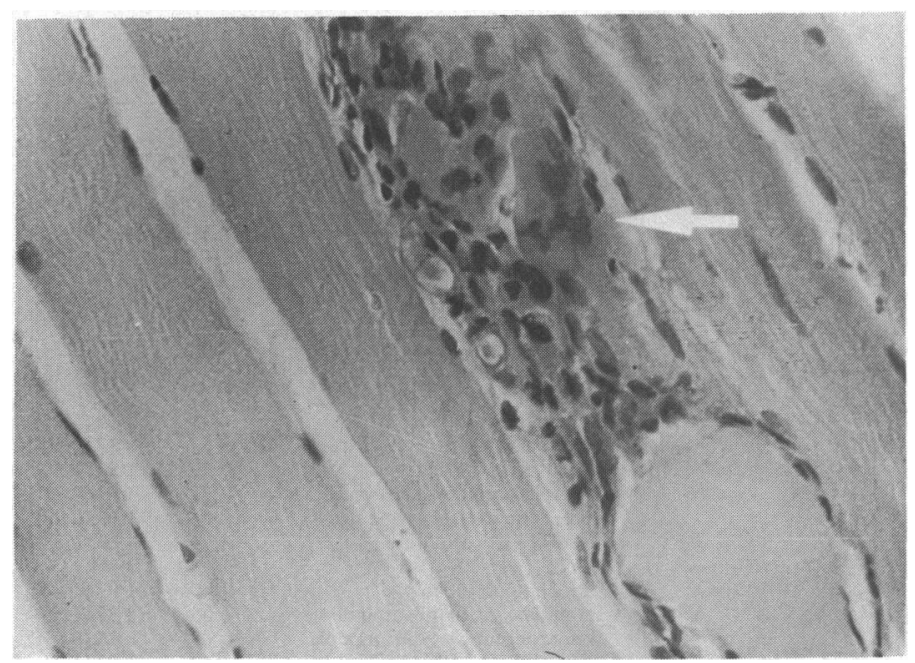

Skeletal muscle biopsy sample showing necrosis and fragmentation (arrowed) with mononuclear cell infiltrate. (Haematoxylin and eosin.)

The patient was given a four day course of chloroquine and was haemodialysed for hyperkalaemia and acute renal failure. The fever settled on the third day of treatment and he was discharged after $\mathbf{1 7}$ days in hospital. One month later he was symptom free.

\section{Comment}

This patient had severe falciparum malaria ${ }^{1}$ with skeletal muscle necrosis. This may have been due to sequestration of parasitised erythrocytes, causing microcirculatory obstruction, ${ }^{2}$ though immune and toxic mechanisms cannot be excluded. The onset of oliguria soon after developing myoglobinuria suggested myoglobin as a possible cause of acute rena failure, especially as there was no hypovolaemia or intravascular haemolysis. Parasite sequestration, ${ }^{1}$ however, may have been another contributory factor.

Hepatic dysfunction, as found in our patient, may occur in falciparum malaria. ${ }^{34}$ The histological picture varies from normal or slight hepatocyte swelling ${ }^{5}$ to hepatocyte necrosis with mononuclear cell infiltration. Cholestasis without necrosis, however, has not been reported

We thank Drs S Ramachandran and C A Herath for the haemodialysis.

World Health Organisation Malaria Action Programme. Severe and complicated malaria. Trans $R$ Soc Trop Med Hyg 1985;80(suppl): 1-50.

2 Miller LH, Usami S, Chien J. Alteration in the rheologic properties of Plasmodium knowlesi infected red cells, a possible mechanism for capillary obstruction. $\mathcal{F}$ Clin Invest 1972;50:1451-5. 3 Patwari A, Aneja S, Berry A, Ghosh S. Hepatic dysfunction in childhood malaria. Arch Dis Child 1979;54:139-41.

4 Ramachandran S, Perera MVF. Jaundice and hepatomegaly in primary malaria. $\mathcal{F}$ Trop Med Hyg 1976;79:207-10

5 Sherlock S. Diseases of the liver and biliary systems. Oxford: Blackwell Scientific, 1985.

(Accepted 23 December 1987)

General Hospital, Colombo, Sri Lanka

H J DE SILVA, MD, assistant physician

A K E GOONETILLEKE, MB, BS, senior house office

N SENARATNA, MB, BS, senior house officer

N RAMESH, MB, BS, house officer

U S JAYAWICKRAMA, MD, FRCP, consultant physician

Faculty of Medicine, Colombo 8, Sri Lanka

K S A JAYASINGHE, MD, MRCP, lecturer in medicine

L R AMARASEKERA, MB, PHD, senior lecturer in pathology

Correspondence to: Dr H J De Silva, Department of Gastroenterology, The Radcliffe Infirmary, Oxford OX2 6HE. 